\title{
ECONOMIC SHOCKS OF THE PANDEMIC IMPACT: THE EUROPEAN CASE
}

\author{
Volodymyr Shevchenko'
}

\begin{abstract}
The purpose of the paper is to identify a nature and forms of the economic shocks generated during the COVID-19 pandemic in 2020 and to assess such shocks implications on the European countries. Such economic shocks have caused many of business companies freezing, contraction of industries and services, recession of economies. Economic shocks specifics and their influence on the European economy are considered. Shocks implications are causing economic recessions and influence on recovery prospects. Implications of economic shocks are argued in order to develop practical guidelines for economic policies. Methodology. Pandemic is a natural event of new coronavirus (COVID-19) spread, which influenced on economic and social life. Therefore a study of pandemic-generated economic shocks are based on interdisciplinary approach including inputs of methods from public health, psychology, classical economics, behavioral economics, institutional economics, systemic analysis. Selected relevant data of pandemic shocks impact of the European countries are assessed. Results. Pandemic of the COVID-19 coronavirus and governmental policies in response have generated a number of economic shocks. Such pandemic shocks are different from previously known economic shocks. Content and forces of pandemic - related shocks are a mixture of natural event and results of preventive public measures. The study has identified content and major forms of pandemic economic shocks, their implications. The major shocks of pandemic are considered: psychological, medical, economic, financial, social. Economic shocks have been defined such as: external shocks, supply and demand shocks, cross-border spillovers of pandemic economic shocks are considered as a major reason of national, regional and world economies slowdown. Specific features of shock in Europe are depending on country-specific levels of infection, economic structures and public policies. Cases of economic recession of shock-ignited countries are differentiated among the European countries and have unpredictable recovery tracks. Practical implications. Specific shocks and recession may require different policies responses. The European countries have used different combinations of monetary, fiscal and direct support instruments. The balance between national policies and international coordination is contradictory. Short-term economic policies should be focused on the economies' recoveries. Medium-term policies should include structural and sustainability instruments, long-term policies should be focused on drivers of innovation, education, research and inclusive development.
\end{abstract}

Key words: pandemic, psychological shocks, medical shocks, economic shocks, supply and demand shocks, financial shocks, recession, EU countries.

JEL Classification: F43, F63

\section{Introduction}

World history shows that extreme natural and political events - infections, floods, earthquakes, wars, political unrests - have generated stresses for population as well as in some cases economic shocks and crises. They usually have generated a number of economic problems - economies contraction, emergency expenses, financial distress, external debt, recovery problems. In each such case economic shocks have played as an ignition for the different economic and financial distresses.

Theactualsituation with the COVID-19pandemic and economic shocks has some similarities with historical events but also substantial differences. The actual case is a quick virus transmission and global coverage as pandemic.

In January 2020, the new coronavirus emerged in one area in China and spread over other countries and continents. In March 2020, it was announced

\footnotetext{
Corresponding author:

${ }^{1}$ National Taras Shevchenko University of Kyiv, Ukraine.

E-mail: svberez2001@gmail.com

ORCID: https://orcid.org/0000-0002-5206-6971

ResearcherID: https://publons.com/researcher/3857505/volodymyr-shevchenko/
} 
the global pandemic of COVID-19 as highly infectable and dangerous coronavirus. The newly COVID-19 pandemic has caused rapid changes in the global economic and social environment.

People became threatened by danger of COVID-19 with no proven medications or vaccines against it. Governments were faced with urgent need to prepare public health to unknown number of infected patients and to identify a proper treatment. The very first task was to prevent a further spread of infection.

Authorities in various countries have introduced emergency measures in the areas of health care as well as severe restrictions regarding social communication, economic activities and isolation of the population to counteract the spread of coronavirus. Lockdown measures have terminated a part of services, domestic and international travel, tourism, retail trade. Such measures have dramatically affected the activities of enterprises and households, the economies, employment. As a result, the companies' finances have been distorted, governments' tax revenues have been eroded, and budget spending has been seriously increased. In order to cover unforeseen expenses, the governments and corporations have borrowed financial liquidity, which increased external debts. The pandemic shocks in result have caused contractions of national economies and recessions. Their complex nature and continuing pandemic are the major reasons of uncertainty of national and global economies.

\section{Economic shocks: nature and major forms}

Economic development have been affecting from time to time by events or changes, which seriously influencing on the state of production, consumption, and macroeconomic situation. Such cases of unexpected influence on economic processes are considering as economic shocks of various content.

Economic shocks have different causes and forms, which leads to different approaches to their study in the research literature. The impact of economic shocks and their influence on different processes are among research issues. The content of economic shocks and their relation to crises were discussed by M. Lettan and S. Ludvigson (Lettan, Ludvigson, 2011); nature of economic shocks and their major forms have been outlined by E. Reed (Reed, 2020). The role of economic shocks in the economy and macroeconomic policy has been overseen by
O. Blanchard (Blanchard, 2010). The economic and financial shocks interrelation, asset pricing and cross-border propagation of macroeconomic shocks during global financial crisis of 2008 was studied by I. Jakard (Jakard, 2011). The role of economic shocks in macroeconomic dynamics has been studied by I. Kalinkova (Kalinkova, 2012). External shocks and modeling of their impact on the economy of Ukraine were analyzed by O. Bazhenova, Y. Bazhenova (Bazhenova, 2016).

Economic shocks are caused by unplanned or uncontrolled events or parameters, which have enforcing impact on the economic processes. Such events would be natural disasters, fundamental changes in macroeconomic indicators, high volatility of commodity and financial markets, economic policy decisions, and significant technological innovations. The main consequences of shocks are changes in economic processes and results, imbalances, recession, asset prices and market excessive volatility, negative expectations of market participants.

The shocks could be structured in two functional groups: 1) endogenous (internal shocks of the economic systems or sectors) and 2) exogenous (shocks caused by external to the economies forces or events - natural, political, social and technological). Respectively, factors of shocks considered: supply, demand, financial and economic policy, technology. Shocks are characterized with interactions; they would have general economic, sectoral, cross-sectoral and regional implications.

Endogenous shocks can be primarily defined of macroeconomic origin, forms and results. For example, common changes in basic macroeconomic parameters like inflation rapid increase or business restrictions would cause endogenous economic shocks to supply, demand, output and productivity.

Endogenous shocks would be identified in economic activities and cause a deviation from normal business processes in case of events of bankruptcy, mergers and acquisitions, restructuring, strikes or systemic changes in business models such as outsourcing, offshoring, robotics, and digitalization. Such shocks are regular component of the process of economic development and growth.

External (exogenous) shocks have three main origins: 1) significant unexpected fluctuations of international markets - commodities (prices and demand changes, trade wars etc.) and financial (interest rates and stock indicators, exchange 
rates, gold prices, capital inflows and outflows); 2) extreme natural events - floods, hurricanes, earthquakes, epidemics, droughts, famines; 3) domestic and external conflicts - military, territorial, political, international, religious.

The sudden and rapid spread of the COVID-19 coronavirus has caused external shocks to national and global economies and societies. In the time of pandemic, the scientific literature is covering the macroeconomic approaches to pandemics in the study of M. Eichknbaumo, S. Redebo and N. Trabandt (Eichknbaumo, Redebo and Trabandt, 2020), features of pandemic economic shocks have been presented and analyzed by A. Kose and N. Sugavara (Kose, Sugavara, 2020), their impact on the economic recession and uncertainty in the studies of O. George, S. Singh and A. Taylor (George, Singh and Taylor, 2020). The nature of pandemic shocks should be identified in order to assess their impact on the economy and financial system.

\section{Economic shocks of pandemic: origin, forms and implications}

The COVID-19 pandemic inspired large-scale quarantines in many countries, restrictions on businesses and travel, which led to contraction of economies and international trade, significant changes in economic and social activities.

This requires focusing the study on the origins, distinctive features and forms of the economic shocks generated during COVID-19 pandemic in 2020. The paper also looks at the implications of pandemic economic shocks for the European countries.

Pandemic is a natural event of new coronavirus COVID-19 spread all over the world, which influenced on economic and social life. The nature of pandemic and its influence on the public life requires the interdisciplinary approach to study of pandemic-generated economic shocks. Pandemic economic shocks need an application of respective research methods of public health, psychology, classical economics, behavioral economics, institutional economics, systemic analysis.

In economic research, there are different approaches and interpretations of the nature and types of economic shocks, their consequences. Shocks are seen as mainly due to economic factors and relationships, such as unexpected macroeconomic changes, cyclical and countercyclical waves, significant fluctuations in prices and demand, internal and external imbalances, economic policies.

The modern pandemic is associated with new and multifactor situation in the societies, countries and international relations. Economic shocks have emerged as a result of the natural factor - newly discovered coronavirus COVID-19, but also due to the anti-virus reactions of the population, governments, and international markets.

The rapid spread of the dangerous COVID-19 coronavirus has caused a shock to health systems, an extraordinary demand for antiepidemic medical services, and a lack of necessary hospitals capacities and medical supplies. Such extreme needs have quickly raised a large international demand for critical medical supplies face masks, protection for medical personnel, special equipment, such as lung ventilation systems. Urgent demand for hospital facilities of specialized infection treatment pursued a quick construction of new hospitals, reconstruction of large public and private spaces such as sports and exhibition halls to be converted for medical services. The shocks to the public health system have caused an extraordinary demand for additional funding that could not be met within budget allocations. Countries have attracted funding from domestic and international sources, including emergency funding from the IMF and other international organizations.

Extent of pandemic economic shocks and their implications have been considered as extreme in the modern history. Professor N. Roubini, a worldknown futurist, who predicted the 2008 global financial crisis, said: "The shock to the global economy from COVID-19 has been faster and more severe than the 2008 global financial crisis and even the Great Depression. In the current crisis, similarly dire macroeconomic and financial outcomes have materialised in three weeks" (Roubini, 2020).

The specificity of current pandemic is that it has generated initial response on virus information as psychological shock, i.e. individual and group reaction on unexpected and stressful event of infection. This causes inadequate emotional reactions: feeling of threat, emotions of danger, fear, public speculation, decisions under stress and uncertainty.

Pandemic-generated economic shocks have differences with known shocks due to their specific origin. Many countries have implemented different measures aimed to prevent spreading of the COVID-19 coronavirus spread. Among such 
measures affected economic activities were the following:

- people on lockdown at homes and restricted walking to the near food shop;

- social distancing, face masks in public places, limits for people gathering;

- many businesses shout down - shops and shopping malls, restaurants, hotels, beauty salons, fitness clubs and other services;

- shift to distance work where possible;

- shift to electronic trade of food and goods, cashless payments;

- shift to distance education in schools and universities, kindergartens closure;

- termination or strong restrictions for transport communication in inner cities, within and between countries;

- countries borders shutdown or restrictions.

Such measures have created or generated in fact "man-made" or "government-imposed" irregularities, which would be considered such as external economic shocks.

Therefore pandemic has generated cluster of shocks with interrelations and contradictory influence on the economic and social life.

- psychological shock as reaction to unexpected threat of infection by deadly coronavirus COVID-19 caused serious and widespread stress and fears; - medical shock in public health during coronavirus COVID-19 due to the danger of large-scale wave of infection, limited hospitals capacities, absence of treatment protocols and vaccine, shortage of medications and equipment;

- economic shocks caused by lockdowns, restrictions and limitations of businesses resulting in contraction of production of goods and services; - financial shocks due to a need to cover extraordinary expenses for fighting against coronavirus, mitigating economic and social consequences of pandemic;

- social shocks are associated with full and hidden unemployment, closure of companies, shift to distance work employment, transfer schools and universities to distance learning.

The main pandemic shocks have specifics as to known economic shocks.

Pandemic demand shocks are considering as result of governments directed limits or closure of businesses, contraction of production of goods and services, restrictions for transport communications. Such situation generated pandemic demand shock for energy, materials, and business services.
Reduced demand has caused prices decline, especially for oil and natural gas, influence on the company losses in that sector. After demand shock, the major oil producers have agreed to reduce supply in order to keep market prices balanced. The situation in turn affected production prospects, depressed investments and had spillover effect of related industries such as equipment and materials producers, oil transportation.

Reduction of electricity consumption is systemic form of demand shock caused by lockdowns, closing of businesses and schools, restrictions for railway transport, etc. In the EU, electricity consumption in April 2020, for example, was $-11.2 \%$ lower than the lowest level in the same month during preceding 5 years. There were some regional differentiations: lowest levels were observed in the most hit by pandemic countries such as: France $15.0 \%$, Spain - 14.6\%, Luxemburg $-13.7 \%$. Seven countries showed more than $10 \%$ decrease, four countries - between $5 \%$ and $10 \%$ less (Eurostat, 2020). Electricity sector is technologically dependable on balance of production and consumption of electricity, therefore demand shock has created some challenges for countries' power generating systems.

Pandemic demand shocks have led to downturn in production of different goods and services, disruptions in international supply chains, crisis in tourism industry and international air transportation. Demand for international air transport fell by $54 \%$ in the second quarter of 2020 , totally 7.5 million flights have been cancelled during half a year; airlines have got 84.8 billion USD losses and have lost 419 billion USD revenues, which accounted 50\% downturn (IATA, 2020).

Pandemic demand shock seriously affected services, which were traditionally accumulated small and medium sized enterprise. Small businesses downturn in many cases has led to shutdowns due to lack of financial reserves and limited opportunities for borrowing on the markets. Therefore SME's future in post-pandemic times looks problematic.

Pandemic supply shock has become evident as change of supply channels and chains. Lockdowns have led to downturn of wholesale trade due to depressed demand for energy, commodities and non-essential imports. International and domestic supply chains have been disrupted and in many cases simplified in order to avoid complexities and delivery risks. Supply stability have supersede cost 
saving as a criteria for supply chains performance. This is also supporting with a trend of reshoring of corporate production facilities back to home countries. Supply shock has led to structural changes in retail trade such as rapid development of e-commerce and trade especially in food supply. Various networks of food delivery have boomed during lockdowns and such trend would look competitive in the future.

Pandemic financial shocks are appearing as an urgent need to meet additional expenses for health care systems operations and supplies, relief for businesses and households, lost revenues of most affected companies and sectors. Tax concessions and debt are major financial implications of shock.

In order to manage response to financial shocks, countries use monetary and fiscal measures. Typical monetary instruments are the downgrading of the central bank's rates to support commercial banks lending, quantitative easing of the money supply, emergency guarantees and loans to support bank's stability.

Urgent financial support is provided by international institutions such as the International Monetary Fund, the World Bank Group, the European Central Bank. One of the consequences of pandemic financial shocks would be further accumulation of domestic and international debt, increase of debt servicing cost.

Pandemic social shock have emerged along with economic shocks, businesses freezing, lockdowns, transport restrictions and appeared as full or partial loss of jobs, shift from traditional to distance organization of work. Social shocks have progressed in second quarter of 2020 and have regional differentiation. Work hours losses (parttime employment, formal employment with no work performed, unemployment) in the second quarter of 2020 have been estimated as: world $14.0 \%$, Americas - $18.3 \%$, Europe and Central Asia $13.5 \%$ (ILO, 2020). Within the European region, differentiation is reflecting a status of the specifics of economies, labor markets and governments relief measures. Work hours losses have been estimated in: Southern Europe - 18.0\%, Northern Europe - 15\%, Western Europe - 14.3\%, Central Asia - 13.6\%, Eastern Europe - 11.6\% (ILO, 2020). The last data also reflects an existence of shadow and contract work in the region, not considered as formal employment and more flexible

Distance work becomes widely used during pandemic lockdowns, but difficult to make reasonable assumptions as for its size and productivity.

The nature and scale of the pandemic economic downturn are considered as the most severe since the Great Depression of 1929-1933 and have caused more losses than the 2008 global financial crisis. Globalization and interdependence of countries contribute to transmission of economic shocks through channels of foreign trade, financial flows, and international communications.

The economic recession in 2020 becomes a major outcome of pandemic economic shocks. Economic recession in the European countries has a high degree of uncertainty, which is causing by pandemic situation and complexity of economic shocks outcomes. Dangerous nature of the COVID-19 coronavirus, fears of possible second wave of pandemic and absence of vaccines make future post-pandemic recovery uncertain. Therefore, the economic and financial prospects of many countries and the world economy look unstable in the short and medium term. The prospects of countries are depending on recession downturn and recovery of different rates in Europe and emerging economies. The latest IMF estimates are giving a comparison of the world and the European countries.

\section{Table 1}

GDP development in 2019 and the forecast for 2020-2021, \% year on year (based on the IMF World Economic Outlook updates in June 2020)

\begin{tabular}{|l|c|c|c|}
\hline & 2019 & $\begin{array}{c}2020 \\
\text { forecast }\end{array}$ & $\begin{array}{c}2021 \\
\text { forecast }\end{array}$ \\
\hline World & 2.4 & -4.9 & 5.4 \\
\hline Developed economies & 1.7 & -8.0 & 4.0 \\
\hline USA & 2.3 & -8.0 & 4.5 \\
\hline Eurozone & 1.2 & -10.2 & 6,0 \\
\hline $\begin{array}{l}\text { Emerging and } \\
\text { developing economies }\end{array}$ & 3.7 & -3.0 & 5.9 \\
\hline Emerging Europe & 2.1 & -5.8 & 4.3 \\
\hline Ukraine & 3.2 & -7.7 & 3.6 \\
\hline
\end{tabular}

Source: compiled by the author based on data (IMF, 2929)

Greater GDP contraction is expecting in Eurozone and developed economies due to intensive pandemic spread and even recovery prospects. Relatively moderate contraction is expecting in emerging and developing economies despite a mixed pandemic situation. GDP forecast for 2021 would reflect an effect of a "low base" of 2020 downturn, while the real achievement of 
pre-pandemic indicators is expected in 2-3 years. Projections for Ukraine should consider the depressed domestic demand, instability of exports and the impact of external debt servicing expenses.

The economic consequences of pandemic economic shocks are differentiated in the European countries due to domestic and international factors such as intensity of the COVID-19 cases, border and transport restrictions, conditions of international trade, instability of international financial markets. Country-specific factors are mostly dependable on economic structures, especially shares of most pandemic-affected sectors like trade, services, tourism as well as fiscal and financial stability.

Table 2

GDP change in the selected EU countries, second quarter of 2020 estimate and 2021 forecast, \%

\begin{tabular}{|l|c|c|}
\hline \multicolumn{1}{|c|}{ Country } & $\begin{array}{c}\text { Change for the } \\
\text { 2 quarter of 2020 }\end{array}$ & 2021 forecast \\
\hline EU 27 & -8.3 & 5.8 \\
\hline Eurozone & -8.7 & 6.7 \\
\hline Belgium & -8.8 & 6.5 \\
\hline Germany & -6.3 & 5.3 \\
\hline France & -10.6 & 7.6 \\
\hline Italy & -11.2 & 6.1 \\
\hline Netherlands & -6.8 & 4.6 \\
\hline Spain & -10.9 & 7.1 \\
\hline Sweden & +5.3 & 3.1 \\
\hline Estonia & -2.7 & 6.2 \\
\hline Hungary & -7.0 & 6.0 \\
\hline Poland & -4.6 & 4.3 \\
\hline Latvia & -7.0 & 6.4 \\
\hline Lithuania & -7.1 & 6.7 \\
\hline
\end{tabular}

Source: compiled by using data (EU, 2020)

Industrially developed countries of the EU, which are most seriously affected by the COVID-19 pandemic (Italy, Spain, France, Sweden), are having a relatively higher GDP contraction compared to the EU. Countries of Central and Eastern Europe (Hungary, Poland, Latvia, and Lithuania) have a lower cases and lesser services sector share, their GDP downturn looks moderately.

Different rates of GDP contraction during a pandemic will affect the chances of recovery. The uncertainty of the recovery would be influenced by the shocks impact on the national and international economies. The uncertainty of the recession and the recovery depends on a number of circumstances:

1) probability and intensity of the next waves of the pandemic and the possible scale in individual countries and regions;
2) time for production and application of the COVID-19 vaccine, its effectiveness and scale of vaccination;

3) changes in business expectations and consumer behavior in the time of recession and recovery.

As a small open economy, Ukraine is experiencing pandemic shocks like other European countries and applies similar policies: face masks, social distancing, restriction of public gathering, freezing of business activities, remote employment, and online trade. The macroeconomic situation looks stable when inflation is still below the planned level of $5 \%$. In the first half of 2020 , the economic performance have seriously downturned (yearto-year): industry - $12.2 \%$, agriculture $-4.0 \%$, transport $-26 \%$, electricity $-8.2 \%$. (NBU, 2020). The impact of economic shocks will be cleared during recovery of the national economy next year.

Simultaneously shocks led to falling prices for oil and natural gas. Reduced demand for imported goods contributing to balancing foreign trade and balance of payments in Ukraine, support relative stability of exchange rate. The outflow of capital is mainly due to the redemption of the government bonds.

\section{Conclusions}

Global pandemic shocks have appeared in several forms: psychological, medical, economic, financial, and social shocks. They have affected economic and social stress, depression and public reaction.

Pandemic shocks have caused differentiated contraction in the European countries due to the cases intensity and different structures of economies. This also would influence on the postpandemic recovery specifics.

Economic shocks have depressed demand on products and services due to lockdowns and crossborder restrictions. Service sector has become the most affected, largest airlines, travel agencies and hotel chains have moved close to insolvency and applied for governmental subsidies. Downsized demand for energy has affected oil, natural gas and electricity prices.

Respectively, supply shocks have disorganized the international supply chains and had impact on the world trade.

Financial shocks have created so-called "pandemic debt" to cover extreme public health needs, economic and social relief spending.

The second wave of pandemic at the beginning of autumn has enforced uncertainty regarding future 
post-recession recoveries, prospects for returning to normal business and social life.

Recovery policies should be based on modern targets and instruments. Short-term policies should be aimed at restoring business and consumption, stabilizing the fiscal and financial situation. Medium-term policy should be focused on macroeconomic stability, external balances and sustainable economic growth.

To strengthen preparedness for future shocks and risks, it would be needed to focus on the innovative development, advanced technologies, big data and artificial intelligence, communication networks and an inclusive social development.

\section{References:}

Bazhenova, O., \& Bazhenova, Y. (2016). Modeling the impact of external shocks on economy of Ukraine: DSGE approach. Ekonomika, vol. 95(1), pp. 64-83.

Blanchard, O. (2010). Rethinking Macroeconomic Policy / IMF staff discussion note. SPN 10/03 International Monetary Fund. Washington, 21 p. Available at: https://www.imf.org/en/Publications (accessed 21 May 2020).

Eichenbaum, M., Rebelo, S., \& Trabandt, M. (2020). The Macroeconomics of Epidemics, NBER Working Paper 26882, 54 p. Available at: www.nber.org/papers/26882 (accessed 21 May 2020).

EU (2020). European Commission. European Economic Forecast. Summer 2020. European Commission. Brussels. July 2020. Available at: https:/ / ec.europa.eu/info/publications/economic-and-financial-affairspublications_en (accessed 21 July 2020).

Eurostat. EU's electricity consumption lover in April 2020. Available at: https://ec.europa.eu/eurostat/ en/web/products-eurostat-news/-/DDN-20200714-2 (accessed 21 May 2020).

Eurostat. Data GDP (2020). Available at: https://ec.europa.eu/eurostat/documents/2995521/ 11156775/2-31072020-BP-EN.pdf/cbe7522c-ebfa-ef08-be60-b1c9d1bd385b (accessed 21 May 2020).

Forbes, K., \& Warhock, F. (2011). Capital flows wawes, surges, stops. flights and retranchments. NBER Working paper, 17351, 38 p. Available at: www.nber.org/papers/17351 (accessed 21 May 2020).

IATA (2020). COVID-19 fourth impact assessment. IATA Geneva. Available at: https://www.iata.org/ en/iata-repository/publications/economic-reports/covid fourth-impact-assessment/ (accessed 21 May 2020).

ILO (2020). Monitor: COVID-19 and the world of work. 5 ed. International Labor Organization. Geneva. Available at: https://www.ilo.org/wcmsp5/groups/public/dgreports/dcomm/documents/ briefingnote/wcms_740877.pdf (accessed 21 July 2020).

Jaccard, I. (2018). Asset pricing and the propagation of macroeconomic shocks. Journal of the European Economic Association, volume 16, issue 2, April 2018, pp. 431-486.

Kalinkova, I. (2012). The Monetary Shock's Wave-Like Diffusion Cross-Analysis through Developed Countries European Applied Sciences. Stuttgart, Germany, no. 1, pp. 447-451.

Lettan, M., \& Ludvigson, S. (2011). Shocks and Crashes. NBER Working Paper 16996. Available at: www.nber.org/papers/16996 (accessed 21 May 2020).

Jordà, O., Singh, S., \& Taylor, A. (2020). The longer run economic consequences of pandemics. Available at: www.vox.org (accessed 21 May 2020).

Kose, A., \& Sugavara, N. (2020). Understanding the depth of the 2020 global recession in 5 charts. World Bank. Available at: https://blogs.worldbank.org/opendata/understanding-depth-2020-global-recession (accessed 21 May 2020).

NBU (2020). Natsionalny bank Ukrainy. Macroeconomichnyi i monetarnyi ogliad. National bank of Ukraine. Macroeconomic and monetary review. Kyiv. Available at: www.bank.gov.ua (accessed 21 May 2020).

Reed, E. (2020). Economic Shocks Definition and Examples. Available at: https://finance.yahoo.com/ news/economic-shocks-definition-examples-221454349.html (accessed 21 May 2020).

Roubini, N. (2020). Coronavirus pandemic has delivered the fastest deepest economic shock in history. The Guardian. 25 March 2020. Available at: https: //www.theguardian.com/business/2020/mar/25/ coronavirus-pandemic-has-delivered-the-fastest-deepest-economic-shock-in-history (accessed 21 May 2020).

IMF (2020). IMF. June 2020 World Economic Outlook update. Available at: https://www.imf.org/en/ Publications/WEO/Issues/2020/06/24/WEOUpdateJune2020 (accessed 21 July 2020). 